\title{
Unconventional Intersection Designs for Improving Traffic Operation Along Arterial Roads
}

\author{
Taqwa Hadidi', Hana Naghawi ${ }^{*}$, Khair Jadaan² \\ 1 Department of Civil and Environmental Engineering, College of Engineering, Virginia Polytechnic Institute and State University, \\ 750 Drillfield Drive, 24061 Blacksburg, VA, USA \\ 2 Department of Civil Engineering, School of Engineering, The University of Jordan, Queen Rania Street, 11942 Amman, Jordan \\ * Corresponding author, e-mail: h.naghawi@ju.edu.jo
}

Received: 11 February 2020, Accepted: 11 March 2020, Published online: 20 October 2021

\begin{abstract}
The main objective of this paper is to evaluate the effect of implementing four Unconventional Arterial Intersection Designs (UAIDs) including median U-Turn, Superstreet, Jughandle and Single Quadrant Intersection on a major arterial road using SYNCHRO microscopic simulation software. For this purpose, Wadi Saqra Signalized Intersection on Shaker Bin Zaid major arterial road in Amman, Jordan was selected. The simulation results showed that only the Jughandle improved the intersection Level of Service (LOS) slightly, F-E. Nevertheless, the intersection delay was significantly reduced by $64.81 \%, 76.6 \%, 91.28 \%$ and $75.60 \%$ on the proposed Median U-Turn, Superstreet, Jughandle and Single Quadrant unconventional intersection design, respectively. This indicated that these UAIDs don't perform well under heavy traffic volumes. Also, since the Jughandle was the only UAID which improved the LOS on the main intersection, the operational performance of Prince Shaker Bin Zaid arterial after implementing the Jughandle at the main intersection was evaluated including the main intersection: Wadi Saqra intersection, one prior to the main intersection and one after the main intersection. It was found that the use of the Jughandle increased the average travel speed by $35 \%$ and decreased the average stopped delay by $28.68 \%$ on the arterial road. Also, this paper evaluated the current transportation system and road user's attitude towards UAIDs' implementation through a questionnaire survey. The results indicated high acceptance of UAIDs. Finally, the construction cost for each UAID type was estimated. It was found that the Jughandle had the highest construction cost due to its high acquisition cost.
\end{abstract} Keywords

Median U-Turn (MUT), superstreet, jughandle, single quadrant, Unconventional Arterial Intersection Design (UAID), microsimulation, SYNCHRO

\section{Introduction}

Intersections are considered as the crucial road network component. Intersections are constructed where two or more roadways meet. The main objective of intersection design is to provide safe, comfortable, and convenient movement of traffic through the intersection. Intersections are classified as signalized intersections or unsignalized intersections depending on the type of traffic control on the intersection approaches. Traffic control development depends on the traffic volumes, it ranges from all way stop under low volume to signal control under moderate to high traffic volume. As the traffic volume increases the demand at intersections increases as well. This leads to congested intersections with longer cycle time, and higher number of phases. In an attempt to reduce traffic congestion, traffic engineers worldwide adopted several conventional measures. These measures ranged from low-cost measures such as improving signal timing and phasing, to high cost ones such as adding lanes along roadways or even grade separation, which is expensive and disruptive to the adjacent land use. However, these measures were unable to permanently address the problem of traffic congestion (Hummer and Reid, 2000). Therefore, agencies and engineers has explored and utilized Unconventional Arterial Intersection Designs (UAIDs). These designs cooperate two design considerations: the first one is improving network performance and the second one is reducing construction and operational cost towards improving mobility for roadway users. There are several types of UAID that exist and have been studied. These Designs include, but not limited to, Median U-Turn, Superstreet, Jughandle, 
Quadrant Intersection, Continuous Flow Intersection, Continuous Greet-T, Parallel Flow Intersection, Bowtie, Split Intersection, and Roundabouts (Hummer et al., 2010). Each type of these UAID's has its own characteristics and there is no superior type that can be implemented globally. The general management strategy and operational principle of the UAIDs consists of: reduction in the number of signal phases, restricting left turn movements across the main intersection and emphasizing on the through traffic movement, and improving intersection operational efficiency and safety by reducing the total number of conflict points (Kim.et al., 2007). The main disadvantage of the UAIDs is the potential driver's confusion as compared with the conventional intersection designs due to the increased number of left turn movements. Moreover, constructing a UAID needs more Right of Way (ROW) to satisfy the desirable design causing higher construction cost. Other disadvantages include more pavements marking, guide signs, and the possible need for longer distance for pedestrians crossing (Hummer et al., 2010).

The main objective of this paper is to test the effect of implementing the Unconventional Arterial Intersection Designs (UAIDs) including Median U-Turn (MUT), Superstreet, Jughandle and Single Quadrant Intersection (SQI) on a heavily congested signalized intersection, as well as on a major arterial road in Amman using TRAFFICWARE SIMTRAFFIC/ SYNCHRO 8. as a microscopic simulation software. Wadi Saqra signalized Intersection, located on Shaker Bin Zaid major arterial road, was selected for this purpose. The intersection services traffic volumes among the most attractive areas in Amman; Shmesani, Zahran, Abdali and Telaa Alali. Also, this paper evaluates the current transportation system and the acceptance level and the attitude of road users towards implementing these UAIDs. Finally, the construction cost for constructing the selected UAIDs was also estimated.

\section{Literature review}

\subsection{Unconventional arterial intersection designs}

Many studies were conducted to evaluate the operational performance of implementing different types of unconventional arterial intersection designs using real world traffic data. Moon et al. (2011) evaluated the implementation of the Superstreet intersection design on a corridor located on the National Highway 38, Gyeonggi-do, South Korea. The corridor consists of three signalized intersections spaced by about $400 \mathrm{~m}$. VISSIM simulation software was used for this purpose. It was found that Superstreet design reduced the total number of stops, delay and total number of crashes. Naghawi et al. (2018a) discussed the possibility of implementing the Superstreet unconventional intersection design on one of the most significant signalized intersections in Amman named Tabarbour using real traffic data. The Microscopic simulation software environments VISSIM and SYNCHRO were used to model and compare the existing intersection to the proposed Superstreet intersection design. Considerable improvement was found after implementing the proposed Superstreet, as the maximum queue length was reduced by $97 \%$ and the average vehicle delay was reduced by $87 \%$, as a result the level of service (LOS) was enhanced from F to C. El Esawey and Sayed (2011) used VISSIM to study the possibility for implementing an Upstream Signalized Crossover (USC) on a major urban corridor located in Doha, Qatar. The corridor consists of three signalized intersections. The analysis was carried out for morning, mid-day, and evening peak hours. It was found that using USC reduced the system delay for all peak hours by $19.4 \%, 14.8 \%$, and $13.6 \%$ for the morning, mid-day, and evening peaks, respectively. While the average control delay was reduced by between $7.6 \%$ and $22.9 \%$.

Other studies were conducted to evaluate the operational performance of implementing different types of unconventional intersection designs using hypothetical traffic data since constructing a live unconventional and conventional intersection design for evaluation purposes is a massive undertaking and not feasible in many circumstances. Zawawa and Naghawi (2021) used SYNCHRO.8 to evaluate and compare the operational efficiency of a conventional signalized T-intersection with an unconventional Continuous Green T-intersection under different congestion levels. A total of 48 hypothetical scenarios, 24 scenarios for each design, were created by changing the approach volumes and turning percentages. The simulation results showed that the Continuous Green T-intersection operates the best under stable traffic conditions and that it is not an effective solution for signalized T-intersections under heavy traffic volume. Naghawi and Idewu (2014) used CORSIM to compare the operational efficiency of a conventional signalized intersection with that of an unconventional Superstreet intersection. Several hypothetical scenarios were created by changing the approach volumes and turning percentages on the major and minor roads to reflect different congestion levels at the intersection resulting in a total of 72 scenarios, 36 for the conventional model and 36 for the Superstreet model. It was found that the Superstreet intersection design consistently showed evidence of decreased delay time and 
queue length when compared to the conventional design. The percentage reduction in the network delay ranged from $27.39 \%$ to $82.26 \%$ and the percentage reduction in the average network queue length was almost $97.50 \%$ when the Superstreet design was implemented.

Other researchers compared the operational performance of different unconventional intersection designs. Autey et al. (2013) compared the performance of four unconventional intersection designs including the Double Crossover Intersection (DXI), the Crossover Displaced Left Turn (XDL), the Median U-Turn (MUT), and the Upstream Signalized Crossover (USC). The analysis was performed using the microscopic simulation software VISSIM. It was found that the lowest delay occurred at the XDL intersection followed by both the DXI and the USC. On the other hand, the MUT did not accommodate high left turn volumes. Also, it was found that the XDL intersection had doubled its capacity compared to the conventional intersection design. Hildebrand (2007) examined the operational performance and the construction cost of five unconventional intersection designs including the Continuous Flow Intersection (CFI), Bowtie, Jughandle, Superstreet, and Median U-Turn (MUT) using SYNCHRO Studio 7 software. He found that MUT and the CFI performed the best but the construction cost was higher by $35 \%$ and $50 \%$ than the conventional design for both MUT and CFI, respectively.

On the other hand, limited research was conducted to evaluate the operational performance of the Quadrant Roadway Intersection (QRI). Reid (2000) used CORSIM to evaluate the improvement of the intersection performance when implementing a new unconventional intersection design called QRI. The results showed significant reduction in the intersection delay which was associated with a $22 \%$ reduction in average travel time when implementing QRI intersection design. In addition, Reid and Hummer (1999) compared conventional intersection with QRI in terms of performance. The study showed a $22 \%$ significant reduction in the total travel time when implementing QRI intersection design. Also, it was found that the QRI performed better than the conventional intersection design under high traffic volumes. Hummer and Reid (2000) examined the QRI performance using different intersection configurations in North Carolina and Virginia. The results indicated that in spite of the longer travel distance for the left-turn, the travel time for left-turn was not considerably greater than the conventional intersection and in case of high traffic volume there was a considerable reduction in travel time during both off-peak and peak conditions. Naghawi et al. (2018b) used SYNCHRO.8 to evaluate and compare the operational performance of three unconventional arterial intersection designs including Median U-Turn, Superstreet, and Single Quadrant Intersection using real traffic data. The effect of implementing each of the proposed designs was not only evaluated on the isolated signalized intersection, but also on the arterial road including both surrounding intersections. The simulation results showed that all three selected unconventional intersection designs outperformed the conventional intersection design in terms of control delay but only the Single Quadrant Intersection design improved the main intersection's LOS from F to B. Also, the results indicated that the Single Quadrant Intersection design resulted in an increase in average travel speed by $52 \%$, and a decrease in the average stopped delay by $34 \%$ on the selected corridor when compared to the corridor with conventional intersection design.

\subsection{Traffic simulation}

Traffic simulation is defined as the use of computer model to represent real world. Simulation is safer, less expensive and faster than field testing. It has become a valuable tool for the analysis and design of road network due its ability to conduct the results of building new links or developing a current network, in other words it assesses the effect of the proposed change on the existing system (Naghawi, 2012).

Depending on the data complexity there are two main traffic simulation models, the FHWA classifies simulation models as macroscopic and microscopic simulation. Microscopic simulation model is defined as the modeling of vehicle movements for assessing traffic performance. It simulates each vehicle characteristics and how it interacts with other traffic stream components. It provides valuable information about the existing transportation system performance and the potential improvements. Macroscopic simulations consider traffic flow as fluid flow by aggregating its characteristics such as volume and speed for the whole traffic stream. That portrays this type of modeling as a simplistic and less time consuming in calibrating the models (FHWA, 2004).

SYNCHRO studio is a microscopic level analysis software. Also, it is a signal optimization software. It implements the Intersection Capacity Utilization (ICU) method for determining intersection capacity. SYNCHRO 8 also supports the HCM 2000 (TRB, 2000) methodology for signalized intersections and roundabouts. Due to its 
simplicity, traffic models are built within days. Moreover, SYNCHRO reports the Measures of Effectiveness (MOE) for the whole network and for each intersection lane or approach (Trafficware, 2011).

\section{Methodology}

The signalized Wadi Saqra intersection was selected to be tested for the proposed UAIDs. It is one of the most significant intersections on the highly congested Prince Shaker Bin Zaid arterial road in Amman, Jordan. The intersection services traffic among the most attractive areas in Amman; Shmesani, Zahran, Abdali and Telaa Alali. The selection of Wadi Saqra was based on the availability of ROW. The operational efficiency of the conventional signalized intersection was compared to those of the proposed unconventional intersection designs. Its effect was tested not only on Wadi Saqra but also on a segment of the arterial road. Fig. 1 shows Wadi Saqra intersection.

\subsection{Data collection}

The key traffic data were available from the department of traffic operations at Greater Amman Municipality reports (GAM, 2014). Traffic data were collected on $6^{\text {th }}$ Oct. 2014. The 15-min peak hour volumes occurred in the evening peak from 7:30 to $8: 30 \mathrm{pm}$. The data included traffic volumes for each direction including left and right turning volumes, gradients, and percentages of heavy vehicles. Table 1 shows the key traffic data on Wadi Saqra Signalized Intersection.

\subsection{Signal timing and phasing}

Traffic signal timing and phasing for Wadi Saqra Intersection were drawn from the department of traffic operations at the GAM. The signal timing and split for the intersection are illustrated in Table 2.

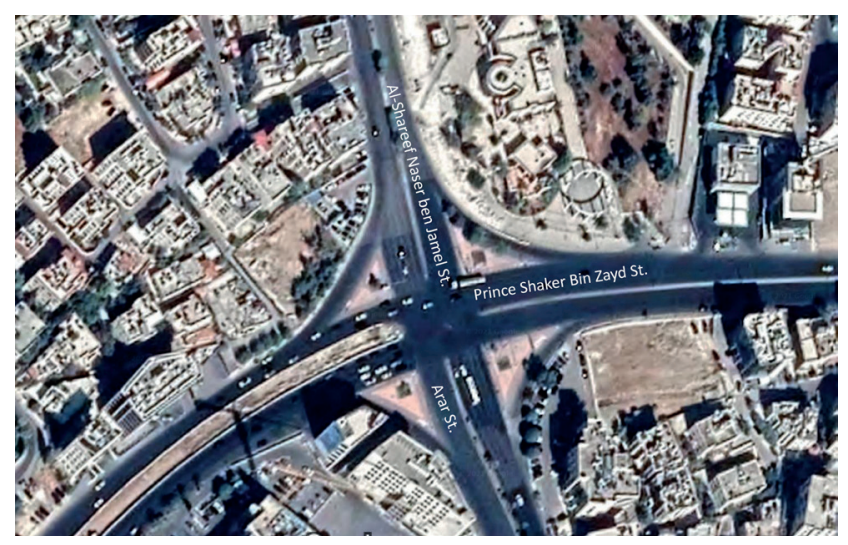

Fig. 1 Wadi Saqra Intersection (Google Map)

\section{Model development}

First of all, the conventional model for Wadi Saqra signalized intersection was created and validated. It was constructed using the existing geometric and traffic data for the intersection. The geometric design for the current situation was imported into SYNCHRO 8 as DXF file from AUTOCAD draft brought from GAM, defining the links' length, number of lanes, lane width, approach volumes and cycle length as shown in Fig. 2. Then, the SYNCHRO software was used to optimize signal phasing and cycle length. It was found that the current signalized intersection operates with optimal signal timing and phasing.

Table 1 Traffic counts on Wadi Saqra Intersection (GAM)

\begin{tabular}{lcccccc}
\hline Approach & \multicolumn{3}{c}{ Eastbound } & & \multicolumn{3}{c}{ Westbound } \\
\hline Movement & Th & L & R & Th & L & R \\
Volume (vph) & 2097 & 1622 & 140 & 1447 & 256 & 1059 \\
PHF & 0.872 & 0.897 & & & & \\
grade & $-3 \%$ & $-9 \%$ & & & & \\
Heavy Vehicles & $2 \%$ & $1.3 \%$ & & & & R \\
Approach & \multicolumn{3}{c}{ Southbound } & & Northbound & \\
\hline Movement & Th & L & R & Th & L & R \\
Volume (vph) & 1002 & 697 & 40 & 249 & 678 & 736 \\
PHF & 0.868 & 0.976 & & & & \\
grade & $-7 \%$ & $5 \%$ & & & & \\
Heavy Vehicles & $3 \%$ & $3 \%$ & & & & \\
\hline
\end{tabular}

Table 2 Wadi Saqra Signal Timing and Split (GAM)

\begin{tabular}{lcccc}
\hline Phase & A & B & C & D \\
\hline & & 165 & & \\
Cycle Time (sec) & & 19 & 38 & 20 \\
Split Percentage (\%) & 23 & 31.4 & 62.7 & 33 \\
Total Split Time (sec) & 37.9 & & & \\
\hline
\end{tabular}

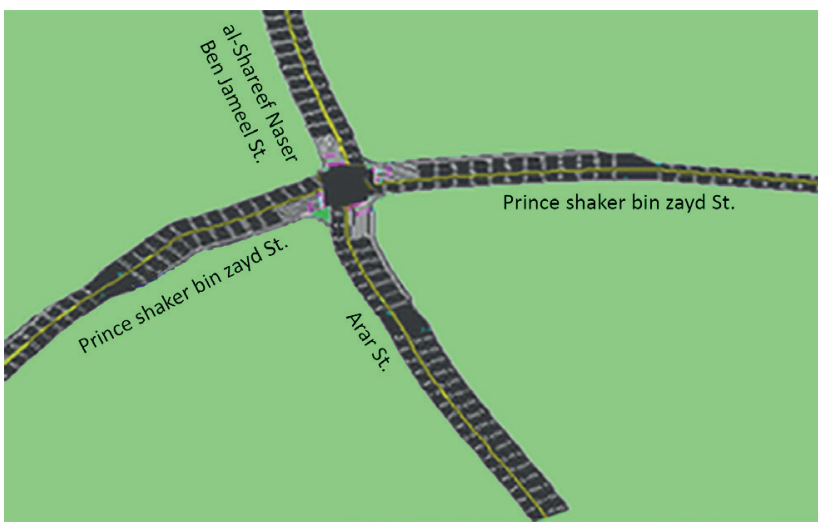

Fig. 2 Wadi Saqra Simulation Model 


\subsection{Model validation}

In this paper the statistical validation was based on the Root Mean Square Percent Error (RMSPE) coefficient using throughput volume as the validation parameter. The throughput volume is defined as the maximum traffic flow which can be served by a lane (Hourdakis et al, 2003). Equation (1) was used to calculate the RMSPE coefficient (Niet al, 2004).

$$
\text { RMSPE }=\sqrt{\frac{1}{N} \sum_{1}^{N}\left(\frac{Y_{\text {sim }}-Y_{\text {observed }}}{Y_{\text {observed }}}\right)^{2}},
$$

where: $N$ is the number of simulation Runs, $Y_{\text {sim }}$ is the simulation run throughput volume, $Y_{\text {observed }}$ is the real throughput volume.

In this research a total of 13 simulation runs were executed. The duration of each run was about one hour. The throughput volume on the Prince Shaker Bin Zaid was 5,279 vehicles. The simulated throughput volumes for the 13 simulation runs are shown in Table 3.

Based on Eq. (1), the RMSPE was calculated to be $6.37 \%$ this value is less than $15 \%$, which is the RMSPE threshold such as the model validation has high accuracy (Hourdakis et al, 2003).

\subsection{UAID model development}

After validating the conventional Wadi Saqra simulation model, the four UAIDs models were created including: Median U-Turn, Superstreet, Jughandle and Single Quadrant Intersection. The geometric design for the UAIDs was imported into SYNCHRO 8 as DXF file from AUTOCAD drawing according to the AASHTO (2004)

\begin{tabular}{lc} 
& Table 3 Simulation Throughput volume (vph) \\
\hline Run ID & Throughput volume \\
\hline 1 & 6,208 \\
2 & 6,222 \\
3 & 6,224 \\
4 & 6,217 \\
5 & 6,389 \\
6 & 5,902 \\
7 & 5,771 \\
8 & 5,980 \\
9 & 6,028 \\
10 & 5,707 \\
11 & 7,394 \\
12 & 7,042 \\
13 & 7,048 \\
\hline
\end{tabular}

standards for a passenger car and for a design speed of $70 \mathrm{~km} / \mathrm{h}$. The proposed UAID models are shown in Figs. 3-6.

\subsection{Model calibration}

Model calibration is defined as the adjustments of model parameters such that the model outputs closely represent the field condition. Speed was selected for the model

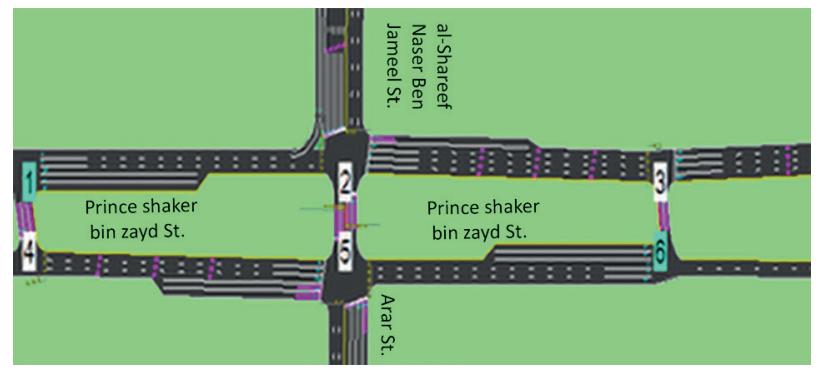

Fig. 3 Median U-Turn Simulation Model

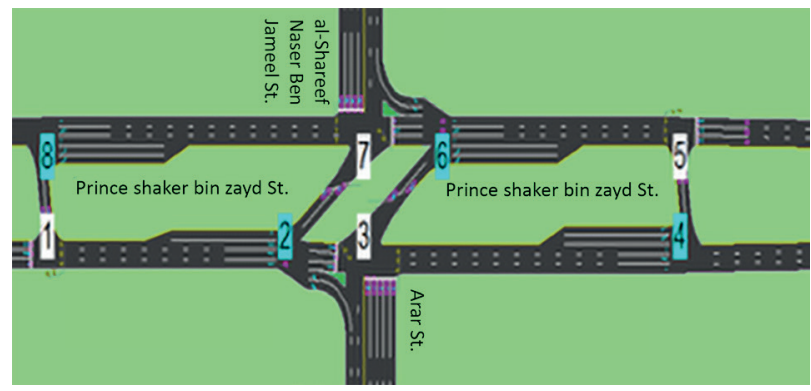

Fig. 4 Superstreet Simulation Model

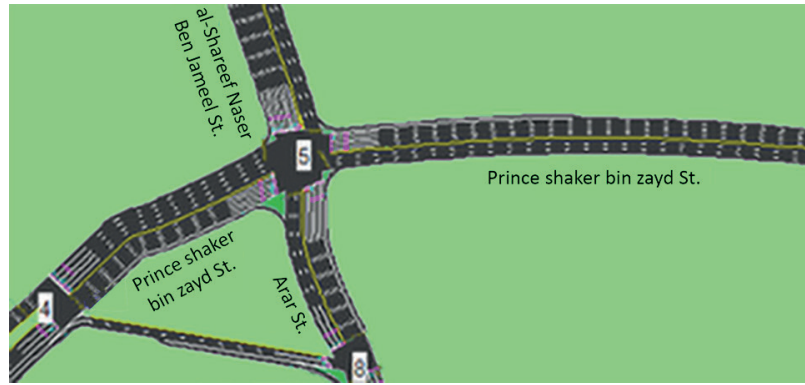

Fig. 5 Jughandle Simulation Model

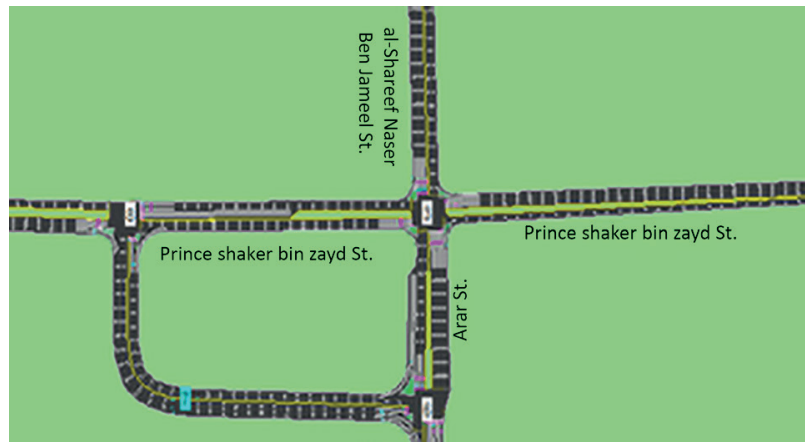

Fig. 6 Single Quadrant Simulation Model 
calibration. The field speed was estimated as the total travel distance divided by the total travel time. The total distance was measured using an AUTOCAD draft drawing adopted from GAM. The total travel time was measured using a stop watch. This procedure was repeated ten times to get the average field speed. The field speed was found to be $23.21 \mathrm{~km} / \mathrm{h}$. This was compared to the simulated speed which was $23 \mathrm{~km} / \mathrm{h}$. These values yielded to a percentage error of $0.009 \%$, which can be neglected.

\section{Operational performance}

In this paper, the operational performance of the existing conventional intersection design and the proposed four UAIDs for the main intersection, Wadi Saqra, were compared first using the level of service (LOS) in terms of the intersection control delay. Then the effect of implementing the UAIDs was tested on a segment of the arterial road, Shaker Bin Zaid, including the intersections prior and after Wadi Saqra intersection using the stopped delay per vehicle and the travel speed. Table 4 shows the operational analysis results for the existing conventional Wadi Saqra signalized intersection and the proposed four UAIDs: median U-Turn, Superstreet, Jughandle and Single Quadrant Intersection. The results include the intersection control delay and LOS.

It can be seen that only the Jughandle improved the intersection LOS slightly, from F to E. Nevertheless, the intersection delay was significantly decreased by $64.81 \%$, $76.6 \%, 91.28 \%$ and $75.60 \%$ on the proposed Median U-Turn, Superstreet, Jughandle and Single Quadrant unconventional intersection designs, respectively. Since the Median U-Turn, Superstreet, and Single Quadrant unconventional intersection designs didn't improve the LOS on Wadi Saqra intersection, only the effect of implementing the Jughandle will be tested on a segment of arterial road including the intersections prior and after Wadi Saqra intersection. Table 5 shows the comparison between the operational performance on the selected segment of the arterial road at the current conventional intersection and that of the proposed Jughandle intersection.

Table 5 shows that the Jughandle's implementation showed a $28.36 \%$ decrease in average stopped delay per vehicle and $35 \%$ increase in average travel speed.

\section{Construction cost estimation}

This section provides an evaluation of the construction cost to improve intersection performance using various UAIDs. In order to achieve this objective, the geometric configuration for each intersection was designed and drawn using
AUTOCAD 2013 considering primordial method for calculating the volumes. The typical cross section consists of four layers: wearing course, binder course, base and subbase with $0.05 \mathrm{~m}, 0.07 \mathrm{~m}, 0.10 \mathrm{~m}$ and $0.30 \mathrm{~m}$ thickness, respectively and with 1:3 side slope. Since this study was conducted based on an existing intersection, the construction costs were calculated only for converting the current intersection to meet the required improvement, in addition to the cost of control devices and land acquisition. The costs for these items were obtained from GAM bids bill of quantities. The item costs were average cost for the bids based on the 2014 prices. The costs for these items are illustrated in Table 6 .

The current conventional ROW permits the construction of the Median U-Turn and the Superstreet UAIDs. Implementing these intersections can be achieved by adding two control devices, traffic signals, for the sub-intersections shown in Figs. 3 and 4. The cost of adding two traffic signals for the Median U-Turn and Superstreet designs, is 300,000 Jordanian Dinar (JD). As for the jughandle intersection, it needs a ramp along the arterial road as shown in Fig. 5. As for the Single Quadrant intersection, it begins with a roadway construction as shown in Fig. 6.

Table 4 Operational Performance Results of implementing the UAIDs on Wadi Saqra Intersection

\begin{tabular}{lcc}
\hline Intersection Design & Control Delay (sec/veh.) & LOS \\
\hline Conventional & 862.20 & $\mathrm{~F}$ \\
Median U-Turn & 303.35 & $\mathrm{~F}$ \\
Superstreet & 201.75 & $\mathrm{~F}$ \\
Jughandle & 75.20 & $\mathrm{E}$ \\
Single Quadrant & 210.4 & $\mathrm{~F}$ \\
\hline
\end{tabular}

Table 5 Operational Performance Results of implementing the Jughandle on Shaker Bin Zaid Arterial Road

\begin{tabular}{lcc}
\hline MOE & $\begin{array}{c}\text { Corridor without } \\
\text { Jughandle }\end{array}$ & $\begin{array}{c}\text { Corridor with } \\
\text { Jughandle }\end{array}$ \\
\hline $\begin{array}{l}\text { Average stopped delay per } \\
\text { vehicle (sec/veh) }\end{array}$ & 137.5 & 98.5 \\
Average travel speed $(\mathrm{km} / \mathrm{h})$ & 23 & 31 \\
\hline
\end{tabular}

Table 6 Unit Costs of various construction items (GAM)

\begin{tabular}{lc}
\hline Item & Unit price (JD) \\
\hline Earthworks (M3) & 4 \\
Surface wearing (M3) & 130 \\
Asphalt binder (M3) & 120 \\
Base (M3) & 18.75 \\
Subbase (M3) & 18 \\
Acquisition cost (m2) & 1,500 \\
Control device & 100,000 \\
\hline
\end{tabular}


The detailed construction cost for the Jughandle and the Single Quadrant designs is shown in Table 7. It can be estimated that, the total cost for constructing a jughandle intersection at Wadi Saqra Intersection is 6,525,820,6 JD including ramp construction cost of 53,465.6 JD and acquisition cost of 6,272,355 JD for a total acquisition area of $4,181.57 \mathrm{~m}^{2}$. Also, Table 7 shows that, the estimated total cost for constructing Single Quadrant Intersection at Wadi Saqra Intersection is 4,598,113.2 JD including 180,761.5 JD cost for constructing the roadway in the Single Quadrant, the acquisition cost of 4,217,351.7 JD for an area of $2,811.5678 \mathrm{~m}^{2}$, and the control devices costs 200,000 JD.

\section{Road user's acceptance survey}

A survey was conducted to evaluate the current transportation system and to assess road user's acceptance about UAIDs implementation to alleviate traffic congestion in Amman. For this purpose, a questionnaire survey was designed and distributed to a sample of road users. The survey population consists of two categories of drivers including commuter and recreational drivers. A sample size of 382 was calculated using an online calculator assuming a confidence interval of $95 \%$ with a marginal error of $5 \%$. The total number of respondents to the survey was 412, including 286 commuter drivers and 126 recreational drivers. The survey was conducted using Google drive format, during the period of 29 October 2014 to 28 November 2014. The information was saved in a database directly after submitting the form; the questionnaire was 3 pages long with an average completion time of 15 minutes.

Table 7 Jughandle and Single Quadrant Construction Cost

\begin{tabular}{|c|c|c|c|c|}
\hline & \multicolumn{2}{|c|}{ Jughandle } & \multicolumn{2}{|c|}{ Single Quadrant } \\
\hline Item & $\begin{array}{c}\text { Volume }\left(\mathrm{m}^{3}\right) / \\
\text { Area }\left(\mathrm{m}^{2}\right)\end{array}$ & Cost (JD) & $\begin{array}{l}\text { Volume } \\
\left(\mathrm{m}^{3}\right)\end{array}$ & Cost (JD) \\
\hline $\begin{array}{l}\text { Earthworks } \\
\text { (cut) }\end{array}$ & 1,258 & 5,032 & $5,126.835$ & $20,507.3$ \\
\hline $\begin{array}{l}\text { Wearing } \\
\text { Course }\end{array}$ & 109.21 & $14,197.3$ & 361.3365 & $46,973.7$ \\
\hline $\begin{array}{l}\text { Binder } \\
\text { Course }\end{array}$ & 152.89 & $18,346.8$ & 505.8795 & $60,705.5$ \\
\hline $\begin{array}{l}\text { Base } \\
\text { Course }\end{array}$ & 218.41 & $4,095.2$ & 722.694 & $13,550.5$ \\
\hline $\begin{array}{l}\text { Subbase } \\
\text { Course }\end{array}$ & 655.24 & $11,794.3$ & $2,168.03$ & $39,024.5$ \\
\hline $\begin{array}{l}\text { Total } \\
\text { Volume }\end{array}$ & & $53,465.6$ & & $180,761.5$ \\
\hline $\begin{array}{l}\text { Control } \\
\text { Device }\end{array}$ & & NA & & 200,000 \\
\hline Acquisition & $4,181.57$ & $6,272,355$ & $2,811.5678$ & $4,217,351.7$ \\
\hline
\end{tabular}

The survey was divided into five parts as follows:

1. Socioeconomic parameters: this part investigates the socioeconomic characteristics of participants including age and gender.

2. Road users' transportation mode: this part compiles road users' mode of transportation and their opinion on Amman's transportation system.

3. Road users' opinion about traffic congestion in Amman: this part estimates road users' problems caused by congestion such as delay and work productivity and also, their opinion about traffic congestion impact on national economy.

4. Road users' opinion about traffic signal performance: this part evaluates road users' opinion about traffic signal performance and their perceived reason of poor performance.

5. Road users' acceptance of UAID implementation: this part investigates, indirectly due to the road users' unfamiliarity with UAID types, the UAID acceptance. This was done by asking the road users about the reason of poor signal performance, and their possibility to use less congested but longer alternatives routes.

\subsection{Survey analysis}

\subsubsection{Socioeconomic characteristics}

The respondents' socioeconomic characteristics are summarized in Table 8.

It can be seen that $69.42 \%$ were commuter drivers, $55.34 \%$ were female drivers, also it can be seen that $75 \%$ of the recreational drivers and $73.7 \%$ of the commuter drivers were between the age of 21 and 30 .

\subsubsection{Mode of transportation}

This part of the questionnaire included two questions:

1. What is your primary mode of transportation? With probable answers including walking, Private vehicle, public transportation, taxi and carpooling.

Table 8 Respondents socioeconomic characteristics

\begin{tabular}{lccc}
\hline \multirow{2}{*}{ Drivers } & Recreational & Commuter \\
\hline \multirow{2}{*}{ Gender } & Female & 72 & 156 \\
& Male & 54 & 130 \\
\hline \multirow{4}{*}{ Age } & $16-20$ & 12 & 26 \\
& $21-30$ & 95 & 211 \\
& $31-40$ & 16 & 37 \\
& $41-50$ & 0 & 10 \\
& $>51$ & 5 & 2 \\
\hline
\end{tabular}


2. How satisfied are you with the current transportation system? With probable answers: not satisfied at all, moderate satisfaction, slightly satisfaction, satisfied, very satisfied.

The results of this part of the survey are shown in Table 9.

Table 9 illustrates that road users in Amman don't walk. Also, it shows that $42.06 \%$ of the recreational drivers and $35.52 \%$ of the commuter drivers use public transportation, $46.03 \%$ of recreational drivers and $47.55 \%$ of commuters use their private vehicles. It also shows that $53.96 \%$ of commuter drivers and $72.73 \%$ of recreational drivers are either not satisfied or not satisfied at all with the transportation system in Amman.

\subsubsection{Road user's opinion about traffic congestion}

This part of questionnaire constituted of six questions:

3. How would you evaluate traffic congestion in Amman? With probable answers: very serious, serious, slightly serious and moderate.

4. Do you face any major problems caused by traffic congestion? With yes or no answers. If yes, continue the survey. If no, Stop.

5. What adverse impact does traffic congestion cause? With probable answers: stress, delay, pollution, inability to estimate travel time and all of the above.

6. Do you think that driving in lack of experience causes traffic congestion? With yes or no answers.

7. Does traffic congestion have an adverse effect on your work productivity? With yes or no answers.

Table 9 Mode of Transportation

\begin{tabular}{|c|c|c|c|}
\hline Question & Probable Answer & Recreational & Commuter \\
\hline \multirow{6}{*}{$\begin{array}{l}\text { What is your } \\
\text { primary mode of } \\
\text { transportation? }\end{array}$} & Walking & 0 & $0.8 \%$ \\
\hline & $\begin{array}{c}\text { Public } \\
\text { transportation }\end{array}$ & $42.06 \%$ & $32.52 \%$ \\
\hline & Private vehicle & $46.03 \%$ & $47.55 \%$ \\
\hline & Taxi & $3.17 \%$ & $3.14 \%$ \\
\hline & Carpooling & $2.38 \%$ & $3.49 \%$ \\
\hline & $\begin{array}{l}\text { More than one } \\
\text { mode }\end{array}$ & $6.36 \%$ & $12.58 \%$ \\
\hline \multirow{5}{*}{$\begin{array}{l}\text { How satisfied } \\
\text { are you with } \\
\text { the current } \\
\text { transportation } \\
\text { system? }\end{array}$} & $\begin{array}{c}\text { Not satisfied } \\
\text { at all }\end{array}$ & $19.84 \%$ & $31.82 \%$ \\
\hline & Not satisfied & $34.12 \%$ & $40.91 \%$ \\
\hline & $\begin{array}{c}\text { Slight } \\
\text { satisfaction }\end{array}$ & $9.5 \%$ & $5.94 \%$ \\
\hline & Satisfied & $35.72 \%$ & $20.28 \%$ \\
\hline & Very satisfied & $0.9 \%$ & $1.05 \%$ \\
\hline
\end{tabular}

8. Do you think that traffic congestion has an impact on national economy? With yes or no answers, if yes what is the level of impact? (very high, high, and small).

Table 10 shows the results of this part of the survey.

Table 10 shows that $60.3 \%$ of the recreational drivers and $52.44 \%$ of the commuter drivers evaluated traffic congestion in Amman as very serious, more than $90 \%$ of the recreational and commuter drivers faced problems due to traffic congestion, $51.58 \%$ of recreational drivers and $53.85 \%$ of commuter drivers responded that delay caused by traffic congestion badly impacts them, $43.53 \%$ of recreational drivers and $53.97 \%$ of commuter drivers believe that traffic congestion is caused mainly due to lack of driving experience, this finding is consistent with the finding by Naghawi (2019). It was also found that about $76 \%$ of

Table 10 Road user's opinion about traffic congestion in Amman

\begin{tabular}{|c|c|c|c|}
\hline Question & Probable answer & Recreational & Commuter \\
\hline \multirow{4}{*}{$\begin{array}{l}\text { How would you } \\
\text { evaluate traffic } \\
\text { congestion in } \\
\text { Amman? }\end{array}$} & Very serious & $60.3 \%$ & $52.44 \%$ \\
\hline & Serious & $23.8 \%$ & $32.87 \%$ \\
\hline & Slight serious & $15.1 \%$ & $14.69 \%$ \\
\hline & Moderate & $8 \%$ & $0 \%$ \\
\hline \multirow{2}{*}{$\begin{array}{l}\text { Do you face any } \\
\text { major problems } \\
\text { caused by of traffic } \\
\text { congestion? }\end{array}$} & Yes & $91.3 \%$ & $94.76 \%$ \\
\hline & No & $8.7 \%$ & $5.24 \%$ \\
\hline \multirow{6}{*}{$\begin{array}{l}\text { What adverse } \\
\text { impact does traffic } \\
\text { congestion cause? }\end{array}$} & Stress & $10.32 \%$ & $12.94 \%$ \\
\hline & Delay & $51.58 \%$ & $53.85 \%$ \\
\hline & Accidents prone & $12.7 \%$ & $5.6 \%$ \\
\hline & Pollution & $2.36 \%$ & $0.7 \%$ \\
\hline & $\begin{array}{l}\text { Inability of travel } \\
\text { time estimation }\end{array}$ & $19.04 \%$ & $15.38 \%$ \\
\hline & $\begin{array}{l}\text { All of adverse } \\
\text { impact }\end{array}$ & $4 \%$ & $10.48 \%$ \\
\hline \multirow{2}{*}{$\begin{array}{l}\text { Do you think that } \\
\text { driving in lack } \\
\text { of experience } \\
\text { contributes to } \\
\text { traffic congestion? }\end{array}$} & Yes & $43.35 \%$ & $53.97 \%$ \\
\hline & No & $56.65 \%$ & $46.03 \%$ \\
\hline \multirow{2}{*}{$\begin{array}{l}\text { Does traffic } \\
\text { congestion have an } \\
\text { adverse effect on } \\
\text { your productivity? }\end{array}$} & Yes & $76.1 \%$ & $76.92 \%$ \\
\hline & No & $23.9 \%$ & $23.08 \%$ \\
\hline \multirow{2}{*}{$\begin{array}{l}\text { Do you think that } \\
\text { traffic congestion } \\
\text { has an impact on } \\
\text { national economy? }\end{array}$} & Yes & $91.3 \%$ & $91.6 \%$ \\
\hline & No & $8.7 \%$ & $19.04 \%$ \\
\hline \multirow{3}{*}{$\begin{array}{l}\text { If you answer } \\
\text { yes on the above } \\
\text { question, is it! }\end{array}$} & Very high & $26.97 \%$ & $29.77 \%$ \\
\hline & High & $48.7 \%$ & $51.91 \%$ \\
\hline & Small & $24.33 \%$ & $18.32 \%$ \\
\hline
\end{tabular}


both recreational and commuter drivers agree that traffic congestion has an adverse impact on their working productivity, more than $91 \%$ of both recreational and commuter drivers agree that traffic congestion has impacts on national economy with more than $75 \%$ believing that traffic congestion highly impact level on national economy.

\subsubsection{Road user's opinion about traffic signal performance}

This part of the questionnaire was conducted by asking the participants to evaluate the traffic signal performance. The response choices were (very poor, poor, accepted, good, and very good). The results are shown in Table 11.

Table 11 shows that $47.6 \%$ of the recreational drivers and $45.45 \%$ of the commuter drivers evaluated signal performance in Amman as acceptable while about $30 \%$ out of the recreational drivers and about $40 \%$ of the commuter drivers consider the traffic signal performance as either poor or very poor performance.

\subsubsection{UAIDs implementation acceptance}

This part was investigated indirectly, due to the users' unfamiliarity with the UAIDs. Users opinion about implementing UAIDs was concluded through asking about the reasons of poor signal performance, and the users' potential to use longer, less congested routes in case of traffic congestion. These questions are considered to be as the key ones regarding UAID. The results are summarized in Table 12.

Table 12 shows that $73.41 \%$ of commuter drivers and $42.2 \%$ of recreational drivers indicate poor signal performance as the reason for the high left traffic volume. As well, it shows that drivers are conscious that the high traffic volume leads to poor signal performance. Also, the table indicates that $90.47 \%$ of the recreational drivers and $88.46 \%$ of the commuter drivers would prefer to use longer, less congested routes in case of traffic congestion. These results may be considered as a promising indicator of high acceptance of UAIDs by road users.

Table 11 Road User Opinion about Traffic Signal Performance

\begin{tabular}{lcc}
\hline Performance & Recreational & Commuter \\
\hline Very poor & $12.7 \%$ & $11.19 \%$ \\
Poor & $17.46 \%$ & $28.67 \%$ \\
Accepted & $47.6 \%$ & $45.45 \%$ \\
Good & $19.07 \%$ & $13.64 \%$ \\
Very good & $3.17 \%$ & $1.05 \%$ \\
\hline
\end{tabular}

Table 12 Road User Opinion about UAID Implementation

\begin{tabular}{lccc}
\hline Question & Reason & Recreational & Commuter \\
\hline & $\begin{array}{c}\text { High left traffic } \\
\text { volume } \\
\text { High through }\end{array}$ & $42.2 \%$ & $73.41 \%$ \\
& $\begin{array}{c}\text { traffic volume } \\
\text { Poor Signal }\end{array}$ & $28.95 \%$ & $12.56 \%$ \\
$\begin{array}{l}\text { Performance } \\
\text { Causes }\end{array}$ & $\begin{array}{c}\text { Poor driving } \\
\text { experience }\end{array}$ & $21.05 \%$ & $2.63 \%$ \\
& $\begin{array}{c}\text { Signal timing } \\
\text { All of the } \\
\text { above }\end{array}$ & $5.26 \%$ & $5.26 \%$ \\
$\begin{array}{l}\text { Potential to } \\
\text { use longer } \\
\text { path }\end{array}$ & Yes & $90.47 \%$ & $8.14 \%$ \\
\hline
\end{tabular}

\section{Conclusion}

The main purpose of this paper is to test and evaluate the effect of implementing four Unconventional Arterial Intersection Designs (UAIDs) including Median U-Turn, Superstreet, Jughandle and Single Quadrant Intersection on a major arterial road using TRAFFICWARE SIMTRAFFIC/SYNCHRO as a microscopic simulation software. For the purpose of this study Wadi Saqra Signalized Intersection on Shaker Bin Zaid major arterial road in Amman/Jordan was selected. The simulation results showed that only the Jughandle improved the intersection level of service slightly, from $F$ to $E$. Nevertheless, the intersection delay was significantly reduced by $64.81 \%, 76.6 \%, 91.28 \%$ and $75.60 \%$ on the proposed Median U-Turn, Superstreet, Jughandle and Single Quadrant unconventional intersection designs, respectively. Since the Jughandle was the only UAID which improved the LOS on the main intersection, after implementing the Jughandle at the main intersection, the operational performance of Prince Shaker Bin Zaid arterial was evaluated including the main intersection: Wadi Saqra intersection, one prior to the main intersection and one after the main intersection. The use of the Jughandle increased the arterial road average travel speed by $35 \%$ and decreased the average stopped delay by $28.68 \%$.

Also, the paper evaluated the current transportation system and road users' attitude towards UAIDs implementation through a questionnaire survey. The survey population consisted of two types of drivers: commuter drivers and recreational drivers. A sample size of 382 was calculated using an online calculator assuming a confidence interval of $95 \%$ with a marginal error of $5 \%$. The total number of respondents to the survey was 412, of which 286 were commuter drivers and 126 were recreational drivers. 
The survey was conducted using Google drive format, during the period of 29 October 2014 to 28 November 2014. The information was saved in a database directly after submitting the form; the questionnaire was 3 pages long with an average completion time of 15 minutes. The survey was divided into five parts. The first part investigated the socioeconomic characteristics of participants including age and gender, it was found that $69.42 \%$ were commuter drivers, $55.34 \%$ were female drivers, and $75 \%$ of the recreational and $73.7 \%$ of commuters were between the age of 21 and 30. The second part explored road users' transportation mode, the analysis results of this part indicated that $42.06 \%$ of the recreational drivers and $35.52 \%$ of the commuter drivers use public transportation, $46.03 \%$ of recreational and $47.55 \%$ of commuters use their private vehicles. Also, $53.96 \%$ of commuter drivers and $72.73 \%$ of recreational drivers are either not satisfied or not satisfied at all with the transportation system in Amman. The third part examined road users' opinion about traffic congestion in Amman. The survey results of this part showed that $60.3 \%$ of the recreational drivers and $52.44 \%$ of the commuter drivers evaluated traffic congestion in Amman as a very serious problem, more than $90 \%$ of the recreational and commuter drivers were facing problems due to traffic congestion, $51.58 \%$ of recreational drivers and $53.85 \%$ of commuter drivers responded that delay caused by traffic congestion has the highest impact on them, $43.53 \%$ of recreational

\section{References}

AASHTO (American Association of State Highway and Transportation Officials) (2004) "A policy on geometric design of highways and streets", American Association of State Highway and Transportation Officals, Washington, DC, USA.

Autey, J., Sayed T., El Esawey, M. (2013) "Operational performance comparison of four unconventional intersection designs using micro-simulation", Journal of Advanced Transportation, 47(5), pp. 536-552.

https://doi.org/10.1002/atr.181

El Esawey, M., Sayed, T. (2011) "Unconventional USC intersection corridors: evaluation of potential implementation in Doha, Qatar", Journal of Advanced Transportation, 45 (1), pp. 38-53. https://doi.org/10.1002/atr.131

FHWA (Federal Highway Administration) (2004) "Signalized intersections: Informational guide", U.S. Department of Transportation, Federal Highway Administration, Washington, DC, USA, Rep. FHWA-HRT-04-091, pp 219-276. [online] Available at: http://www.fhwa.dot.gov/publications/research/ safety/04091/04091.pdf [Accessed 03 March 2014] drivers and $53.97 \%$ of commuter drivers believe that traffic congestion is caused mainly due to lack of driving experience, about $76 \%$ of both recreational and commuter drivers agree that traffic congestion has an adverse impact on their working productivity, more than $91 \%$ of both recreational and commuter drivers agree that traffic congestion has an effect on the national economy with more than $75 \%$ believe that traffic congestion highly impacts the level of national economy. The fourth part of the survey observed road users' opinion about traffic signal performance. It was found that $47.6 \%$ of the recreational drivers and $45.45 \%$ of the commuter drivers evaluated traffic signal performance as acceptable. In the fifth part, which is the most important part in this survey, road user's opinion about UAID implementation was concluded. It showed that $73.41 \%$ of commuter drivers and $42.2 \%$ of recreational drivers indicated poor signal performance as the reason for the high left traffic volume. As well, it showed that drivers are conscious that high traffic volume leads to poor signal performance. It also indicated that $90.47 \%$ of the recreational drivers and $88.46 \%$ of the commuter drivers would prefer to use longer less congested routes in case of traffic congestion. These results may be considered as a promising indicator of high acceptance of UAIDs by road users.

Finally, the construction cost for each UAID type was estimated. It was found that the Jughandle had the highest construction cost which exceeded six million Jordanian Dinar.

GAM (Greater Amman Municipality, Traffic Operation Department) (2014) "Traffic Data Reports", Amman, Jordan.

Google Maps [online] Available at: https:/www.google.com/maps/ place/بs\%2\%80\%AD/@31.9655451,35 $.8881675,17 \mathrm{z} / \mathrm{data}=! 3 \mathrm{~m} 1 ! 4 \mathrm{~b} 1 ! 4 \mathrm{~m} 5 ! 3 \mathrm{~m} 4 ! 1 \mathrm{~s} 0 \times 151 \mathrm{ca} 05 \mathrm{~b} 10 \mathrm{fff} 291$ : $0 \times 76$ d 1d 5e86c4c69af! 8m 2!3d31.9655451!4d35.885978 8 [Accessed 20 March 2014]

Hildebrand, T. (2007) "Unconventional Intersection Designs for Improving Through Traffic along the Arterial Road", MSc Thesis, Florida State University.

Hourdakis, J., Michalopoulos, P. G., Kottommannil, J. (2003) "Practical Procedure for Calibration Microscopic Traffic Simulation Model", Transportation Research Board: Journal of the Transportation Research Board, 1852(1), pp. 130-139.

https://doi.org/10.3141/1852-17

Hummer, J. E., Reid, J. D. (2000) "Unconventional Left-Turn Alternatives for Urban and Suburban Arterials: An Update", Transportation Research E-Circular, [online] Available at: http:// onlinepubs.trb.org/onlinepubs/circulars/ec019/Ec019_e3.pdf [Accessed: 01 January 2015] 
Hummer, J. E., Haley, R. L., Ott, S. E., Foyle, R. S. (2010) "Superstreet Benefits and Capacities", U.S. Department of Transportation, Federal Highway Administration, Washington, DC, USA, Rep. FHWA/NC/2009-06. [online] Available at: https://rosap.ntl. bts.gov/view/dot/20271 [Accessed: 19 March 2015]

Kim, M., Lai, X,, Chang, G.-L., Rahwanji, S. (2007) "Unconventional Arterial Intersection Designs Initiatives", In: IEEE Conference on Intelligent Transportation Systems, Seattle, WA, USA. [online] Available at: http://attap.umd.edu/wp-content/uploads/2015/09/ UAID_IEEEITS2007.pdf [Accessed: 01 April 2015]

Moon, J.-P., Kim, Y.-R., Kim, D.-G., Lee, S.-K. (2011) "The potential to implement a superstreet as an unconventional arterial intersection design in Korea", KSCE Journal of Civil Engineering, 15(6), pp. 1109-1114. https://oi.org/10.1007/s12205-011-1157-1

Naghawi, H. (2012) "Methodological Notes on Regional Level Validation of Microscopic Traffic Simulation Model", Jordan Journal of Civil Engineering, 6(2), pp. 186-201. [online] Available at: https://jjce. just.edu.jo/issues/paper.php?p=2339.pdf[Accessed: 10 January 2015]

Naghawi, H. (2019) "Analysis of Young Drivers' Safety in Jordan Using the Quasi-Induced Exposure Method", Advances in Transportation Studies: An International Journal, 47, pp. 111-124.

https://doi.org/10.4399/9788255233489

Naghawi, H., AlSoud, A., AlHadidi, T. (2018a) "The Possibility for Implementing the Superstreet Unconventional Intersection Design in Jordan", Periodica Polytechnica Transportation Engineering, 46(3), pp. 122-128.

https://doi.org/10.3311/PPtr.11635

Naghawi, H. H., Idewu, W. I. A. (2014) "Analysing delay and queue length using microscopic simulation for unconventional intersection design Superstreet", Journal of the South African Institution of Civil Engineers, 56 (1), pp. 100-107. [online] Available at: http://www.scielo.org. za/scielo.php?script=sci_arttext\&pid=S1021-20192014000100011 [Accessed: 11 January 2015]
Naghawi, H., Jadaan, K., Al-Louzi, R., Hadidi, T. (2018b) "Analysis of the Operational Performance of Three Unconventional Arterial Intersection Designs: Median U-Turn, Superstreet and Single Quadrant", International Journal of Architectural, Civil and Construction Sciences, 11.0(3).

https://doi.org/10.5281/zenodo.1474325

Ni, D., Leonard II, J.D., Guin, A., Williams, B.M. (2004) "Systematic Approach for Validating Traffic Simulation Models", Transportation Research Record: Journal of the Transportation Research Board, 1876(1), pp. 20-31.

https://doi.org/10.3141/1876-03

Reid J. D. (2000) "Using quadrant roadways to improve arterial intersection operation", Institute of Transportation Engineers, ITE Journal, 70(6), pp. 35-45.

Reid, J. D., Hummer, J. E. (1999) "Analyzing System Travel Time in Arterial Corridors with Unconventional Designs Using Microscopic Simulation", Transportation Research Record: Journal of the Transportation Research Board,1678(1), pp. 208-215. https://doi.org/10.3141/1678-25

Trafficware (2011) "Synchro Studio 8: Synchro plus SimTraffic and 3D Viewer", Trafficware, Ltd., Sugar Land, TX, USA. [online] Available at: https://www.scribd.com/doc/235631454/SynchroStudio-8-User-Guide [Accessed: 11 January 2015]

Transportation Research Board (TRB) (2000) "Highway Capacity Manual: HCM 2000", TRB, Washington, DC, USA.

Zawawa, G., Naghawi, H. (2021) "Evaluation of the Operational Performance of Continuous Green T-Intersection under Different Levels of Congestion", Periodica Polytechnica Transportation Engineering, 49(1), pp. 66-73. https://doi.org/10.3311/PPtr.14032 